\title{
FROM A "CHILD OF LIGHT" TO A "WOMAN OF GENIUS": SARAH GRAND'S THE BETH BOOK AS THE NEW WOMAN BILDUNGSROMAN
}

\author{
DE "HIJA DE LA LUZ" A “MUJER DE GENIO": THE \\ BETH BOOK, DE SARAH GRAND COMO EL \\ BILDUNGSROMAN DE LA NUEVA MUJER
}

ILONA DOBOSIEWICZ

University of Opole, Poland

ildob@uni.opole.pl

\begin{abstract}
The New Woman fiction, popular in the last decade of the $19^{\text {th }}$ century, contested the traditional notions of gender roles and participated in the public debates on women's rights. The protagonists of the New Woman novels refused to conform to the submissive and self-abnegating Victorian ideal of femininity. The article discusses the ways in which Sarah Grand, a prominent New Woman novelist and social activist, uses and transforms both the elements of her own life and the Bildungsroman conventions in her 1897 novel The Beth Book to create a heroine whose growth and development result in her personal independence and her active public engagement in women's issues. Cast in a variety of social roles, Beth Maclure reclaims her agency and becomes an embodiment of the New Woman.
\end{abstract}

Keywords: New Woman novels, Sarah Grand, The Beth Book, Bildungsroman.

\section{Resumen}

La ficción de la Mujer Nueva, popular en la última década del siglo XIX, cuestionó las nociones tradicionales de los roles de género y participó en los debates públicos sobre los derechos de las mujeres. Las protagonistas de las novelas de Mujer Nueva se negaron a ajustarse al ideal victoriano sumiso y abnegado de la feminidad. El 
artículo analiza las formas en que Sarah Grand, una destacada novelista y activista social de la Mujer Nueva, utiliza y transforma tanto los elementos de su propia vida como las convenciones del Bildungsroman en su novela de 1897 The Beth Book para crear una heroína cuyo crecimiento y desarrollo dan como resultado su independencia personal y su participación pública activa en temas de mujeres. Elegida en una variedad de roles sociales, Beth Maclure recupera su agencia y se convierte en una encarnación de la Mujer Nueva.

Palabras clave: novelas de Mujer Nueva, Sarah Grand, The Beth Book, Bildungsroman.

\section{Introduction: Sarah Grand and the New Woman Fiction}

During her long life, Sarah Grand (1854-1943) played a variety of public social roles: she was a prolific journalist, credited with coining the term "New Woman"; she was an activist who supported women's suffrage and campaigned for rational dress, and she authored a number of New Woman novels. The New Woman fiction, which enjoyed its heyday in the 1890s, was "challenging more radically than ever before the traditional concepts of the feminine role", claims A. R. Cunningham in a pioneering study of the genre (1973: 178). The New Woman novels, often openly didactic, popularized debates on femininity, marriage and women's rights, contesting the traditional notions of gender. By 1890 the voices participating in these debates became more insistent in their demands for improved education, women's suffrage, equitable divorce laws, and new employment opportunities. With educational and employment prospects for women expanding, marriage followed by motherhood was no longer perceived as the only available path towards financial security and personal fulfillment. The heroines of the New Woman fiction, free-spirited, striving for independence, uninterested in matrimony and motherhood, posed an obvious threat to the conventional Victorian ideal of femininity. Their creators, the New Woman authors Olive Schreiner, George Egerton, Mona Caird and the male writers Grant Allen and George Gissing, to name just a few, were often feminists and social reformers, who contributed to the fight for women's rights by representing female characters refusing to conform to the submissive and self-abnegating ideal of womanhood, epitomized by the figure of the Angel in the House. ${ }^{1}$ In her classic study A Literature of Their Own, Elaine Showalter maintains that "in the 1880 s and 1890 s, women writers played a central role in the formulation and popularization of feminist ideology" (1977: 182). Following a similar line of thought, Juliet Gardiner points out that New Woman novels "testified to the power of fiction as an alternative means of exploration and a manifesto for change" (1993: 4). Within the group of New Women writers who 
were instrumental in shaping public debate and policy on a wide range of women's issues, Sarah Grand has been considered "the most interesting of the novelists who engaged their fiction with the political issues of the new woman" (Sutherland 1989: 257).

Sarah Grand contributed to the public debate through her journalism, her civic activism, and her novels. She published The Beth Book, Being a Study of the Life of Elizabeth Caldwell Maclure, A Woman of Genius in 1897. The novel is the final installment of a three-part series which deals with social and individual constraints facing middle-class women and participates in the ongoing debate on marriage as an instrument of women's oppression. The Beth Book was preceded by Ideala (1888) and The Heavenly Twins (1893). The critical and commercial success of The Heavenly Twins — called by a contemporary critic “a bomb of dynamite", which became a publishing sensation, selling twenty thousand copies in the first year after publication (Stead 1894: 67) — established Sarah Grand's reputation as a preeminent New Woman writer. The Beth Book, described by John Sutherland as the "most thoroughgoing portrait of the new woman in fiction" (1989: 61), raises some fundamental questions concerning women's roles in late-Victorian society. The novel opens with an epigraph from Shakespeare's Othello; when Iago tells Emilia to hold her peace, she defiantly responds: "I'll be in speaking, liberal as the air:/ Let heaven, and men, and devils, let them all,/ All, all, cry shame against me, yet I'll speak". The New Woman writers created fictional heroines who, like Emilia, did not hesitate to speak, and thus contributed to complex social changes which resulted in a redefinition of gender roles and solidified the notion of women's rights. The protagonists of the New Woman novels were self-reliant, daring, intelligent and outspoken; thus, they affronted conventional notions of Victorian femininity.

Calling the New Woman "the harbinger of cultural, social and political transformation" and "a vibrant metaphor of transition", Ann Heilmann argues that the New Woman fiction is a "genre which gave cultural resonance to the political concerns of the Victorian and Edwardian's women's movements, while also enabling the writers to problematize and recreate, in their heroines, aspects of their personal experience as women, feminists, and artists" (2000: 1, 5). This combination of the political and the personal characterizes The Beth Book, where Grand incorporates many aspects of her own biography into the story of the growth and development of her heroine, who is cast in a variety of social roles, finally becoming a political activist, and a member of a feminist community. Heilmann notes that the New Woman fiction, with its focus on "issues of personal significance in the lives of the writers (childhood, socialization, education, marriage, sexual inequality and exploitation, artistic development, feminist 
awakening and political activism)", can be regarded "as a genre which drew on auto/biographical forms of writing" (2000: 71).

On an immediate level the reader notices many correspondences between the life of Frances Elizabeth McFall (née Clarke), who wrote The Beth Book under her penname Sarah Grand, and the life of her heroine, Elizabeth Caldwell Maclure. Just like her protagonist, Sarah Grand was born in Northern Ireland into a middle-class family. Her father, like Beth's, was a Royal Navy lieutenant serving as a coastguard stationed in Donaghadee on the northeast coast of Ireland. On her father's death in 1861 the family returned to England and settled in Scarborough. The genteel poverty of Grand's childhood is portrayed in the chapters of The Beth Book set in Castletownrock. Grand's education was similar to Beth's: she received a small legacy from a maiden aunt, which paid her tuition at two boarding schools for the daughters of naval officers; however, her education was much inferior to that of her brothers. These experiences are mirrored in the plot of the novel. Like Beth, Sarah Grand married young. When she was sixteen, she married an army surgeon, Lieutenant-Colonel David Chambers McFall, who was portrayed in the novel as Beth's husband, Daniel Maclure. Gillian Kersley, Sarah Grand's biographer, assumes that as Medical Officer for the Orford Barracks, David McFall would have had close ties to the local lock hospital where prostitutes could be detained and examined under the provisions of the Contagious Diseases Acts. Beth's husband is also involved with the lock hospital (Kersley 1983: 110). However, what makes The Beth Book particularly interesting is not merely the way in which Sarah Grand tells her personal story through her protagonist but the way in which she makes use of the conventions of the Bildungsroman in her representation of Beth's growing consciousness and emerging self.

The present article aims at demonstrating that in The Beth Book Sarah Grand reconceptualizes nineteenth-century fictions of female development. The narrative conventions such as the marriage plot or the story of women's self-sacrifice and renunciation are used by the author only to be ultimately transcended —unlike many heroines of the Bildungsroman, Beth does not become socialized into traditional gender roles, but realizes her potential in the public sphere where her autonomous creative and professional needs are fulfilled.

\section{The Female Bildungsroman}

The Bildungsroman has traditionally been perceived as a genre concerned with the education and formation of a young man who has to find a place for himself in a new social situation. Beginning with Goethe's Wilhelm Meister's Apprenticeship, the novels tracing the lives of their protagonists from early childhood, depicting 
their movement to maturity, became increasingly popular. The innocence and vulnerability combined with misguided ambitions and youthful idealism of the Bildungsroman hero lead to problems that have to be resolved in the course of the novel, resulting in the protagonist's education, maturation, and ever-growing selfawareness. In the early but still influential study of the English Bildungsroman Season of Youth: The Bildungsroman from Dickens to Golding, Jerome Buckley notes that the English Bildungsroman is often autobiographical and its hero goes through such phases of development as formal education, leaving home, making his way in the city, experiencing two love affairs, and actively interacting with society. He points out that the protagonist of the Bildungsroman (the Bildungsheld) is by definition a child whose idealistic tendencies are at odds with a prosaic community (1974: 17). Buckley concludes that the Bildungsheld "brings his own inner resources of sensitivity to confront a hostile and insensitive environment" and courageously withstands and transcends social and cultural pressures (1974: 282). Buckley conceptualizes the Bildungsroman as an individualistic genre which portrays a successful entrance of a young man into adult society.

While Buckley has discussed the Bildungsroman as a genre concerning men growing up and maturing, in the past forty years feminist critics have pointed out that there exist some fundamental differences between male and female developmental patterns; thus, the specificity of the female Bildungsroman should be recognized and critically examined. In their influential essay collection The Voyage In: Fictions of Female Development, (1983), the editors attempt to identify "distinctly female versions of the Bildungsroman" (Abel et al. 1983: 5). They note that in the female Bildungsroman, women do not have as many choices as men, for they are restricted geographically by the lack of mobility and educationally by limited access to even a repressive schooling. Female protagonists are also circumscribed by few choices of available occupations, with the majority of options restricted to the private sphere. In the fictions of female development, the transformation of the protagonist often takes place later in life, after she has been unable to find fulfillment in the traditional roles of wife and mother. However, in their quest for female autonomy, the protagonists experience a significant continuity of relationships from childhood to adulthood, a continuity where family bonds, especially those between mother and child, remain intact. Abel et al. point out that while a traditional Bildungsroman usually has a linear structure, the female Bildungsroman sometimes takes the form of the novel of awakening whose structure is not chronological or linear; instead, the narrative is moved forward through a series of epiphanic moments. Yet, what both male and female Bildungsromane continue to share is a belief in the possibility of development. However, 


\title{
Ilona Dobosiewicz
}

\begin{abstract}
women's developmental tasks and goals, which must be realized in a culture pervaded by male norms, generate distinctive narrative tensions - between autonomy and relationship, separation and community, loyalty to women and attraction to men. The social constraints on female maturation produce other conflicts, not unique to female characters, but more relentless in women's stories. Repeatedly, the female protagonist $[\ldots]$ must chart a treacherous course between the penalties of expressing sexuality and suppressing it, between the costs of inner concentration and of direct confrontation with society, between the price of succumbing to madness and of grasping a repressive 'normality'. (Abel et al. 1983: 12-13)
\end{abstract}

It is worth noting that because of these conflicts the female protagonists of the Bildungsroman acquire a deeper awareness of the fact that their personal development takes place in the context of existing social structures and human relationships; and that it is also influenced by historical events.

The Bildungsroman is a significant form in Victorian literature: numerous novels - e.g., Charles Dickens's Great Expectations, Charlotte Brontë's Jane Eyre, William Thackeray's Pendennis, or George Eliot's The Mill on the Floss - portray the process of maturation of young people. The more recent studies of the Victorian Bildungsroman draw attention to the fact that such a dynamic period as the Victorian era, often called the age of transition, produced a variety of discourses about growing up, "with the growing person forced to live out in her or his life the gaps that endlessly emerge between the old and the new" (Maynard 2006: 282, emphasis added). ${ }^{2}$ Maynard's use of the pronoun her in his discussion of the Bildungsroman as a form of Victorian novel arises out of the recognition that female growth to maturity follows a very different path from that of a young man growing up. As George Levine points out, "[w]hile the male Bildung concentrates on the upward mobility of the young man making his way in Victorian society, the female version, because women have no such economic mobility, tends to focus on the possibility of a good marriage: women are not so much liberated by the new social and economic systems as reconstrained" (2008: 89). In Victorian novels female development may be represented in contradictory ways because female Bildung frequently involves movement towards active social engagement and participation in the public sphere, and this is a movement which stands in contradiction to Victorian notions of femininity privileging self-effacement and the private sphere for women.

\section{Beth Maclure's Growth and Development}

Tracing the development of her heroine's growing consciousness, Grand created in The Beth Book a rich and complex protagonist who embodies many ambiguities and contradictions of Victorian femininity. Grand begins her novel just before 
Beth's birth, which brings to mind perhaps the most famous Victorian Bildungsroman, Charles Dickens's David Copperfield (1850), with its oft-quoted opening "Whether I shall turn out to be the hero of my own life, or whether that station will be held by anybody else, these pages must show" (Dickens 2004: 13). Entitling her novel The Beth Book, Being a Study of the Life of Elizabeth Caldwell Maclure, A Woman of Genius, Grand gives an affirmative answer to Copperfield's query: Beth will turn out to be the heroine of her own life. The early reviewers did not take kindly to the title. In an anonymous review, The Spectator ridiculed what was described as "a new and somehow silly method of nomenclature [...] suggesting to ribald reviewers such variants as The Bob Book, The Bill Book, The Tom, Dick and Harry Book" ("Review of Sarah Grand" 1897: 691). The reviewer went on to say that "[ $\mathrm{t}]$ he book so far justifies its aggravating and strangely sounding title in that the reader is never allowed to lose the sight of Beth for a single moment" (691). Yet, as Jenny Bourne Taylor argues, the novel's title conveys 'the double sense of 'Beth's Book' and 'The Book of Beth' with its Biblical connotations" (2013: 9). Such a doubling suggests that Beth's developing consciousness will construct a multilayered self that cannot be reduced to a single model of femininity. The use of the phrase "A Woman of Genius" in the subtitle of the novel also points to the complexity of its protagonist. In her discussion of the expression "woman of genius" in the late nineteenth century, Penny Boumelha demonstrates that the very phrase "is a calculated challenge to prevailing medical and physiological theories, and therefore to the social orthodoxies and programs built upon them" (1997: 172). The woman of genius "represents a claim to creativity and intellectual power" (173), a claim that, one might add, stands in contradiction to the conventional ideology of womanhood.

It is worth noting that Sarah Grand's novel poses a challenge not only to traditional constructions of womanhood but also to certain literary traditions. Although the novel appears to echo the autobiographical fiction of the mid nineteenth century, Ann Heilmann has shown that the opening of the novel "immediately and ironically sets out to explode these traditions" by calling Beth's very existence into question (2004: 85). Beth's mother, "weak and ill and anxious, the mother of six children already, and about to produce a seventh on an income that would have been insufficient for four", never had an idea that "much of her misery was perfectly preventable" (Grand 2013: 25). If Beth's mother had chosen to practice birth control, the heroine would not have been born. On the other hand, the narrative form of the novel is quite traditional: the author uses omniscient narration focalizing on the female protagonist. ${ }^{3}$

Although the subtitle of Grand's novel with its phrase "a Study of Life" suggests that the heroine's life will be presented in its entirety, from her birth to her 
burgeoning career as a public speaker supporting the rights of women, more than half of the novel is devoted to Beth's childhood and early adolescence. Such a focus reflects a growing interest in the workings of the child's mind which developed in the second half of the nineteenth century. As British psychologist James Sully (1842-1923), one of the leaders in the child study movement, humorously observed in the closing decades of the nineteenth century, children had become the object of scientific scrutiny, as "the tiny occupant of the cradle has had to bear the piercing glance of the scientific eye" (1881: 545). According to Jenny Bourne Taylor, late-nineteenth century science and psychology started to conceptualize a child as a "growing consciousness", a notion which provided a "powerful and poignant embodiment of the idea of both human interiority and collective development" (1998: 91). As Sally Shuttleworth argues in The Mind of the Child, during the latter part of the nineteenth century, post-Darwinian psychology and psychiatry placed the child within a collective narrative of human development as an embodiment of both the past and the future. In terms of the concept of recapitulation, according to which the development of the individual of a species mirrors evolutionary change within the species, the child incorporated change through development but also recalled humanity's evolutionary past. The above-mentioned James Sully draws on the theory of recapitulation in his Studies of Childhood (1895). Shuttleworth points out that Sully perceived the infant as characterized not only by animal appetites but by beginnings and cornerstones of human moral sense and myth-making capacity. He was interested in the connections between language, thought and self-consciousness. Sully considered childhood a time when a multi-layered psychic structure of the individual was laid down; the structure that later shaped all aspects of adult identity (Shuttleworth 2010: 281282). Such a concept of childhood is echoed in The Beth Book: like Sully, Sarah Grand appears to be fascinated by the workings of her heroine's consciousness from her infancy onwards.

Grand's representation of Beth's childhood seems to reflect Sully's ideas on the development of consciousness. Upon her birth, Beth "had been as unconscious as a white grub without legs", but the sunshine "called her into conscious existence" (Grand 2013: 33). The heat and light of the Sun "roused her", called forth the first response of her senses and "quicken[ed] her intellect [...] with the stimulating effort to discover from whence her comfort came. [...] [S] he was born to be a child of light" (34). The development of Beth's mind is stimulated by a physical experience, which indicates the physical basis of the mind, an idea which Grand shares with Sully. ${ }^{4}$ Grand calls this moment Beth's "first awakening" and then proceeds to the next step: her heroine's "awakening $[\ldots]$ to a kind of selfconsciousness" (34). She connects the development of Beth's self-awareness with the development of her brain and her senses: "all of Beth that was not eyes at this 
time was ears, and her brain was as busy as a squirrel in the autumn, storing observations and registering impressions" (42). She describes the ways in which certain associations emerge, stressing the role of the senses in the process of "the involuntary association of incongruous ideas" (41). These associations form Beth's early memories and shape her sense of self and of the surrounding world.

The initial chapters of the novel reveal Beth's mind as open to new experiences, eager to form new connections between various physical phenomena, and learning to formulate some abstract concepts. It is worth noting that Beth's mind possesses different layers of consciousness which link the past with the present. In Chapter III, Grand describes "a strange dream [...] which made a lasting impression upon her" (2013: 51). Beth dreamed that she was "in a great bare cave [...]. There were a number of people, and they were all members of her own family, ancestors [...] distant relations" (51). For a time, Beth keeps wondering "how it was she knew those people were her ancestors", as she "had never heard [...] of ancestors" (51). The narrator speculates that there might exist "some more perfect power to know than the intellect - a power lying latent in the whole race, which will eventually come into possession of it; but with which at present, only some few rare beings are perfectly endowed" (51). A future woman of genius, as a young girl Beth possesses this extraordinary power which makes her aware of the existence of an inexplicable layer of consciousness, "some sort of vision which opened up fresh tracts for her" (52). The narrator wonders whether such a layer may be "hereditary memory, a knowledge of things transmitted to [... Beth] by her ancestors along with their features, virtues, and vices" (51). The notion of hereditary memory brings to mind Carl Jung's concept of the collective unconscious, whose contents "owe their existence exclusively to heredity" (1990: 42), or a more recent claim by neuroscientists that there exists a form of genetic memory that could be passed between generations. Beth's emerging consciousness is a palimpsest of past and present experiences and impressions; her inner world a multilayered and multifaceted microcosm. Grand constructs Beth's childhood not just as a stage in a process of achieving maturity, but as a period when a complex psychic structure of the self which will shape all aspects of her heroine's adult identity acquires its foundations.

Sarah Grand's exploration of Beth's inner self and the workings of the unconscious mind may tempt one to perceive the author of The Beth Book as a forerunner of certain modernist tendencies in literature. Indeed, some critics have located New Woman fiction at the early stages of modernism. In her influential 1992 study The 'Improper' Feminine: The Women's Sensation Novel and the New Woman Writing, Lyn Pykett argues that New Women writers "anticipated the attempts of Dorothy Richardson and Virginia Woolf to develop a specifically feminine voice and form for fiction" (1992: 195-196). Molly Youngkin points out that many New Woman 
novels focus on "consciousness and subjective experience" which aligns them with the beginnings of modernism (2007: 8). As mentioned above, the form of The Beth Book is rather traditional; yet, even within the conventions of a realist narrative the reader encounters some stylistic experiments associated with modernism, such as the dream sequence discussed above.

By representing Beth's mind, Grand explores the role of education in developing the mental faculties of her heroine, exposing Victorian prejudice against female education. As a child, Beth needs to be "formed and developed" (Grand 2013: $337)$; a talent within her "lies latent [...] awaiting favourable conditions to develop itself" (235). However, Beth's mother deliberately neglects her needs in favor of her brother. When Aunt Victoria bequeaths to Beth some money intended for the girl's education, Beth's mother persuades her to finance her brother's education instead. She tells Beth: "There is no hurry for your education. In fact, I think it would be better for your health if you were not taught too much at present" (245). Mrs. Caldwell then undertakes to give Beth lessons in English, music, and French, although she is poorly qualified for such tasks. She "salved her own conscience" for her daughter's perfunctory education, "by arguing that it is not wise to teach a girl too much when she is growing so fast" (269). Mrs. Caldwell's views echo Victorian beliefs that brain work depletes energy from a girl's reproductive organs and thus constitutes a serious threat to her femininity. As a Victorian physician, James Compton Burnett, put it, "the girl's brain saps the pelvis of its power" (1895: 89). Beth unequivocally rejects such views and demands the same right to be educated as boys and men enjoy, and to explore other options in life. As a young girl, she gets into a heated argument with her childhood acquaintance Alfred Cayley Pounce, who claims that girls can do nothing "except marry and look after her husband and children". When he "superciliously" denies talent to women, Beth responds forcefully: "How do you know? [...] Robbing women of the means to develop their talents doesn't prove they haven't any. The best horseman in the world could never have ridden if he hadn't had a horse" (Grand 2013: 267-268).

Beth makes it clear that without proper training and experience girls are "robbed" of the crucial human capacity to develop into mature adults, and refuses to accept that. She wants to train and develop her mind and cultivate her genius: "I shall want to do more, I know. I shall want to be something; and I shall never believe that I cannot be something until I have tried the experiment" (Grand 2013: 268, emphasis in original). She doubts whether masculine minds "were any larger and more capable than the minds of women would be if they were properly trained and developed", and she begins to read the books men "prided themselves on having read, to see if they were past her comprehension" (294). By reading Pope's 
translations of the Iliad and the Odyssey or studying Latin grammar, Beth has developed "tastes of her own" (294). Referring to Beth's "mind in the process of forming itself" the narrator draws attention to her special qualities: "she pursued the cultivation of that in herself which is beyond our ordinary apprehension, that which is more potent than knowledge, more fertilizing to the mind - that by which knowledge is converted from a fallow field into a fruitful garden" (295296). Interestingly, the narrator uses images associated with fertility in reference to knowledge, a trope which provides a significant counterpoint to the conventional Victorian views on the dangers of excessive brain work having an adverse effect on women's reproductive capability.

Grand makes use of spatial metaphors to convey the development of Beth's mind from childhood to womanhood. Beth's discovery of her special gifts takes place against the backdrop of the wild countryside that she is free to roam. Beth's freedom of movement and her desire to explore the physical world around her are associated with the emergence of her artistic gifts and her talent for storytelling. She designs elaborate make-believe games for her sister and her childhood friends; she spontaneously creates short pieces of original poetry, and she is responsive to the influence of the natural environment. However, her free spirit is curbed when she is sent to a boarding school with a repressive regime which drastically limits her freedom of movement. The Royal Service School for Officers' Daughters, modeled after the Royal Naval School in Twickenham, which Sarah Grand attended, has been chosen by Beth's mother because it is "a strict school" that could put an end to Beth's "running wild" (Grand 2013: 299). Although she has yearned for education, the school experience turns out to be deeply disappointing for Beth: she feels "suffocated" there. Accustomed to open spaces, she finds it oppressive that she is "not allowed to go on the grass, nor must $[\ldots]$ run in that unseemly way" (311). Other students suffer from nervous disorders as a result of such limitations, but Beth finds a way out of the school's confined space and begins to take nightly walks that allow her to experience "an ecstasy of liberty" (329), improve her health, and inspire her imagination. Beth's escapades result in her expulsion from the school, but she feels no regrets: the education she received there was as limited as the school spaces: it "was an insult to the high average of intelligence" of its students (315).

The next school Beth attends is a finishing school in London, described as "a forcing house for the marriage market" (Grand 2013: 335). The narrator explicitly states that "at that time marriage was the only career open to a gentlewoman, and the object of her education was to make her attractive" (337-338). Beth spends only several months there, because her mother, disconsolate after the death of her eldest daughter, wants Beth to return home. Beth has never enjoyed a close and 
supportive relationship with her mother: Mrs. Caldwell has always favored her other children and has often been cross with Beth, scolding or even hitting her. While describing Beth's childhood, the narrator points out that among "Beth's many recollections of these days, there was not one of a caress given or received, or of any expression of tenderness", and that Beth sometimes felt the "hard thump" of her mother's "clenched fist" (38). Back at home, Beth experiences "the inevitable friction, the shocks and jars of difficulties and disagreements with her mother" (347). Representing the relationship between the heroine and her mother as fraught with problems, Grand departs from the common pattern of the female Bildungsroman characterized by a close and sustained bond between the mother and the child. She appears to anticipate some patterns of representations that characterize twentieth-century fiction. In The Mother/Daughter Plot, Marianne Hirsch argues that the common twentieth-century representational paradigm of the mother/daughter relationship is one of perpetual conflict (1989: 103), and such a perpetual conflict characterizes Beth's relationship with Mrs. Caldwell. To escape the constraints and hopelessness of her home life, Beth accepts the proposal of Dr. Daniel Maclure, whom she barely knows, thinking that it might give her a certain amount of independence from her mother. Thus, she begins the next stage of her life: her marriage.

The following chapters trace the gradual disintegration of the relationship between Beth and her husband, who turns out to be a cruel and demanding person, a philanderer who openly cheats on his wife with one of his female patients, a man who is wasteful with money and obsessed with social appearances. Beth and Daniel have no shared interests, no common system of values, and expect different things from marriage. The "happy sense of well-being" which she experiences during "the early days of her married life" dissipates quickly (Grand 2013: 357). Her husband, in addition to being financially irresponsible and incurring debt, turns out to be a possessive and controlling man. He takes over the management of her finances, opens and reads her letters, and constantly invades her private space. He "would break in upon her reading with idle gossip, fidget about the room when she wished to meditate and leave her no decent time of privacy for anything" (363). Beth "suffer[s] miserably from the want of privacy in her life" (363); moreover, as a married woman she feels obliged to give up "her free, wild, wandering habits" (372). Having first "lost touch with nature" she "was losing vitality too" (372). In the course of her marriage, Beth becomes depressed, less interested in the open spaces of nature, and less physically active.

Grand's handling of Beth's and her husband's spaces reveals the injustices of the institution of marriage and exposes gender privilege: in their new home, Daniel's territory expands whereas Beth is deprived of any space that she could call her 
own: "He had his consulting room, a room called his laboratory, a surgery, and a dressing room, where no one would dream of following him if he shut the door; she had literally not a corner" (Grand 2013: 364). Exploring their new house in search of a place where she could spend some time alone, she discovers an unused small attic room, "a secret spot, sacred to herself, where she could be safe from intrusion" (365). The room looks "as if ... [it] had only lately been occupied" (365); in the words of Ann Heilmann, "it is [...] the repository of a submerged female tradition waiting to be discovered and inhabited [...]; with its embroidered chairs and mahogany bookcase, vases and flower ornaments, it points back to a female predecessor with artistic tastes, and forward to Beth's imminent transformation into an artist" (2000: 185). The room becomes Beth's refuge, where she can deposit her childhood memorabilia, her books, and her writing materials. Furnishing her hideaway with objects associated with her past, Beth forges a link between her childhood, her present time, and the past life of the former occupant of the room; all these elements become parts of "a submerged female tradition" (to use Heilmann's words), a tradition which Beth's actions revive and reclaim. Her mind receives a much-needed stimulation; having arranged her own space, Beth exclaims: "I am at home, thank God! I shall be able to study, to read and write, think and pray, at last, undisturbed" (Grand 2013: 366).

Highlighting the importance of her own space for the intellectual and artistic development of her heroine, Sarah Grand anticipates the ideas put forward in Virginia Woolf's A Room of One's Own (1929). Like Sarah Grand, Virginia Woolf is concerned with the plight of women of genius, symbolized by the figure of Shakespeare's sister, and points out that female genius can flourish only when it is unencumbered by financial dependency or lack of privacy. In an oft-quoted passage, Woolf maintains that "a woman must have money and a room of her own if she is to write fiction" (1989:4). Beth's own room opens up new possibilities for her: she can immerse herself in "reading [...], writing, and perhaps the most important of all, reflecting, as she sat in her secret chamber" (Grand 2013: 387). Having her own room not only facilitates the development of Beth's intellectual capacities but also gives her a chance to gain a modicum of financial independence: she engages in paid needlework, creating "beautiful embroideries" (387) which she secretly sells through a depôt in London. Her endeavors allow her to establish connections with the outside world where her identity is not reduced to being a wife; instead, she is recognized as a designer and maker of beautiful objects, a person engaged in productive and profitable work. Woolf has pointed out that "masterpieces are not single and solitary births; they are the outcome of many years of thinking in common", and she traces a rich female tradition from Aphra Behn through Fanny Burney, Jane Austen, George Eliot and the Brontës (1989: 65-66). Beth is well aware of the significance of such tradition. As a young girl, she 
argued with a boy who told her that " $[\mathrm{m}]$ en write books, $[\ldots]$ not women". Being "better informed", Beth immediately pointed out that "[w] omen do write books, and girls too. Jane Austen wrote books, and Maria Edgeworth wrote books, and Fanny Burney wrote a book when she was only seventeen, called 'Evelina,' and all the great men read it" (Grand 2013: 194). Later, when she embarks on a course of intense reading and writing, which her own room makes possible, she feels the importance of her connection with past women writers: "as she read of those who had gone before, she felt a strange kindred with them” (388). As Virginia Woolf remarked, "we think back through our mothers if we are women" (1989: 76).

Beth's immersion in books and her resulting mental development allow her to distance herself from the problems of her unhappy marriage: her "mind $[\ldots]$ came steadily more and more under control, and grew gradually stronger as she exercised it. She ceased to rage and worry about her domestic difficulties, ceased to expect her husband to add to her happiness in any way" (Grand 2013: 388). She starts to write down her own ideas inspired by the books she has read, and her writing becomes an escape from the constraints of marriage. Reading George Sand's autobiography and the biographies of the Brontës, she gains a deeper understanding of female experience. She is "uplifted by their aspirations, and glorie[s] in their successes" (388), emotions which give her a much-needed confidence in her own writing endeavors. The female tradition offers her models, as well as a space for growth and development. Having rejected the contemporary art-for-art's sake aesthetics, Beth strives to find her own style. She treasures writing for the opportunity to convey a significant message to the readers: "I would rather have written a simple story, full of the faults of my youth and ignorance, but with some one passage in it that would put heart and hope into some one person, than all that brilliant barren stuff" (394), she declares. She intends to "write for women, not for men" (394). As Teresa Mangum has put it, "[h]er aesthetic, which emerges from her attention to women's daily lives, provides forms and language in which to express her political views. Most important [...], Beth's aesthetic is unapologetically an ethics driven by her desire to transform society from within the male dominated world of letters" (1998: 10). Beth's room becomes a site for meaningful work that combines the manual skills required for embroidery and the intellectual capacities exerted through her writing. Because of the self-discipline she practices there, she develops the moral courage that will help her to confront her husband at home and will later turn her into an advocate for other women in the public sphere.

Beth's decision to write for women points towards her future career as a public speaker on women's issues. Interestingly, her marriage becomes an important phase in her development as a public person, when she is forced to confront the highly topical public issues of lock hospitals and the practice of vivisection. Early in her 
marriage, she remained unaware of her husband's involvement with a lock hospital, an institution where prostitutes suffering from sexually transmitted diseases were effectively imprisoned. Beth was isolated from other women, who shunned her because they believed that she was complicit in her husband's activities in a lock hospital. In time, she managed to form closer ties with a group of women in her community, who later informed her of her husband's morally abhorrent work. Another mark of her husband's moral degradation is his keen interest in vivisection, a practice which amounts to torturing animals in the name of medical research. When Beth discovers a dog tied up on a vivisecting table in her husband's surgery, it is "a sight too sickening for description [...]. Beth had heard of these horrors before, but little suspected that they were carried on under that very roof" (Grand 2013: 453). Beth could have learned of the horrors of vivisection from feminist publications which often featured anti-vivisection editorials, since in the last decades of the nineteenth century, anti-vivisection advocacy was frequently tied to the advocacy of women's issues. For example, Frances Power Cobbe, a prominent women's suffrage campaigner, was a founder of such animal advocacy groups as the National Anti-Vivisection Society and the British Union for the Abolition of Vivisection. Beth's discovery of her husband's vivisection experiment carried out in their home is a crucial moment in the novel, when the domestic space becomes a site of a morally repugnant practice associated with the public sphere. Beth manages to channel her sympathy for an animal in excruciating pain into action: she administers poison to put the dog out of its misery. Her action restores her sense of agency which has been undermined in the course of her disastrous marriage: after the mercy killing of the dog, "she felt the stronger for a brave determination, and more herself than she had done for many months" (453).

Beth's "brave determination" gives her strength to confront her husband about his morally repugnant practices and assert her own moral standards which do not allow for the cruelty of vivisectors towards animals or the cruelty of doctors towards women humiliated and violated in lock hospitals. Beth is aware that her husband's involvement in vivisection is a sign of his moral degeneration and realizes that such moral failings of men have dire consequences for women. Her private marital problem has an obvious public dimension. Beth refuses to tolerate Dan's behavior not only for her own sake, but also for the sake of other women who suffer abuse by morally bankrupt men. She tells her husband:

I am not going to have any of your damnable cruelties going on under the same roof with me. I have endured your sensuality and your corrupt conversation weakly, partly because I knew no better, and partly because I was the only sufferer, as it seemed to me, in the narrow outlook I had on life until lately; but I know better now. I know that every woman who submits in such matters is not only a party of her own degradation, but connives at the degradation of her whole sex. (Grand 2013: 455) 
Beth has developed a new consciousness of her position as a woman, a consciousness that arises from her realization that her own suffering is interwoven with the suffering of others; thus, her way of coping with her private experience will have public consequences. She feels responsible for other women and she knows that she has to confront her husband for the sake of society's moral improvement. Such a realization is made possible due to Beth's interactions with other women, thanks to whom she has become interested in feminist issues. Strenuously objecting to vivisection, Beth uses the arguments of the feminist anti-vivisection campaigners such as Dr. Elizabeth Blackwell, a physician and a fervent opponent of the use of vivisection in medicine, and Frances Power Cobbe. While confronting Dan, Beth makes a clear connection between her husband's vivisection activities and his work as a doctor in a Lock Hospital, and her argument, which exposes the hypocrisy of the practice that would "punish the women, and let the men go free to spread the evil from one generation to another as they like" (Grand 2013: 459), is presented in the public language of the press. Grand has Beth pick up a copy of the Times and read aloud to Dan excerpts from an article that is a verbatim transcription of a report of the International Congress of Legal Medicine. As Talia Schaffer has observed, "many New Women incorporated non-fiction manifestos into their novels"; she has pointed out that such "examples of passionate argument seem to violate the novel's verisimilitude", and constitute an act of rebellion against "high Victorian realism" (2013: 735).

The effect of the author's departure from the established realist patterns is that it forces the reader to pay close attention to the arguments made by the heroine. Thus, the theme of Beth's rebellion against her husband is reinforced by Sarah Grand's rebellion against narrative convention. It is a sign of Beth's intellectual growth that she can confidently argue with her husband about sexually transmitted diseases and about the legitimacy of his position as the doctor of a Lock Hospital. As she tells Dan, "women have grown out of their intellectual infancy [...] and have opinions and a point of view of their own in social matters" (Grand 2013: 459). This is a crucial scene in the novel and a crucial moment in Beth's development: the domestic conflict between husband and wife becomes intertwined with the public issues; moreover, while formulating her arguments against vivisection and lock hospitals, Beth uses the language of public discourse on women's issues, anticipating her further engagement with public life.

Beth decides to leave her husband, and she plans to pursue her literary career in London, where she is supported by a group of sympathetic and like-minded women. Drawing attention to the importance of a community of women in Beth's life, Grand appears to foresee and respond to Virginia Woolf's call for the creation of fictional heroines who "have other interests besides the perennial interests of domesticity" (1989: 83). Beth becomes a working woman, whose identity is 
developed through her professional pursuits and through her relationships with other women. With the proceeds from her first book and the income gained from her embroidery, she can now afford her own lodgings. Encouraged by her female friends, she devotes herself to writing on women's issues. Her intellectual labor, which has given her enough strength to leave her husband, allows her to establish an independent life and public identity, and her engagement in the public sphere further promotes her personal growth.

However, even "the woman of genius" cannot avoid the conflict between autonomy and relationships which characterizes many female Bildungsromane. In London, Beth gets to know her neighbor, Arthur Brock, an American artist, and when he falls ill, she gives up her own work to minister to his needs. For a brief moment, Beth becomes an embodiment of Victorian self-sacrifice and renunciation: she spends her days nursing him, she spends her money, sells gowns and even her hair to pay his medical bills and buy food for him, and starves herself to the point of collapse. Significantly, it is female solidarity that saves Beth: her friend Angelica (the heroine of Grand's earlier novel, The Heavenly Twins) rescues her and provides her with a space to recover and find herself, the Ilverthorpe Cottage. Once again Grand indicates the importance of having her own space for Beth's development: "A few months in her lovely little house sufficed to restore Beth's mind to its natural attitude —an attitude of deep devotion" (Grand 2013: 537). Her friend is also instrumental in helping Beth to discover her true vocation: she asks Beth to speak at a large meeting and Beth realizes where her true calling and true power lie: she had "spoken to a hostile audience and fascinated them by the power of her personality, the mesmeric power which is part of the endowment of an orator" (539). Beth discovers that her way of doing things for women is not through writing but through public speaking on their behalf; it is her "vocation — discovered by accident" but "when the call had come, and the way in which she could best live for others was made plain to her, she had no thought but to pursue it" (539). The novel ends with an image of Beth awakening to her true vocation: she makes a deliberate decision to enter public life, because she strongly believes in women's issues and in her own ability to become their advocate, and the reader has a sense that a promising career as a public speaker awaits its heroine.

\section{Conclusion}

In her discussion of the female Bildungsroman, Marianne Hirsch shows that woman's consciousness often awakens to limitation, as the female protagonist gains an awareness of a world hostile to female growth and development and adopts strategies of withdrawal culminating in death (1983: 23-48). In The Beth 
Book, Grand challenges and subverts such conventions. Beth's story is not one of disillusionment and compromise, but one of promise and potential. Beth awakens to a life of productive labor, and her engagement in the public sphere becomes a means of promoting her personal growth. She successfully escapes the frustrations of her childhood and her unhappy marriage; moreover, her individual development is represented as separate from her marriage. Beth is not thwarted by biology or destiny and succeeds in her efforts to fulfill her potential. She becomes an embodiment of the claims of women to intellectual and creative equality with men and becomes recognized as "a great teacher $[\ldots]$ a woman of genius" whose words give comfort and hope to "those that suffer" (Grand 2013: 541). She achieves an unconditional public success and emotional fulfillment. In her Bildungsroman, Sarah Grand creates a protagonist who manages to overcome many obstacles and finds her own way, who reclaims her agency and becomes actively involved in her own development, who possesses an ability to use her experiences as tools for personal growth, and who finds a way to exert a positive influence on society. The idea of Beth's growth and maturation is associated with the idea of social progress. Beth's involvement in the struggle for equality between men and women and her public commitment to women's causes turn her into a New Woman, a complex and multidimensional character capable of growth and change.

\section{Notes}

1. The title of Coventry Patmore's collection of poems The Angel in the House (1854-1863), a classic expression of elevated domesticity, provided a popular name for this model of femininity.

2. See for example Freiman (1993), Ellis (1999) and Salmon (2019).
3. For an interesting discussion of Grand's narrative strategies, see Saudo-Welby (2015).

4. Sully's thinking was influenced by George Henry Lewes's classic work on the mind/body relation, The Physical Basis of Mind (1877).

\section{Works Cited}

ABEL, Elizabeth, Marianne HIRSCH and Elizabeth LANGLAND. 1983. "Introduction". In Abel, Elizabeth, Marianne Hirsch and Elizabeth Langland (eds.): 1-22.
Abel Elizabeth, Marianne HIRSCH and Elizabeth LANGLAND. (eds.). 1983. The Voyage In: Fictions of Female Development. Hanover: University Press of New England. 


\section{"The Beth Book" as the New Woman Bildungsroman}

Boumelha, Penny. 1997. "The Woman of Genius and the Woman of Grub Street: Figures of the Female Writer in British Fin-de-Siècle Fiction". English Literature in Transition 40 (2): 164-180.

Compton Burnett, James. 1895. Delicate, Backward, Puny, and Stunted Children: Their Developmental Defects, and Physical, Mental, and Moral Peculiarities Considered as Ailments Amenable to Treatment by Medicines. London: Homeopathic Publishing

Cunningham, A.R. 1973. "The 'New Woman Fiction' of the 1890's". Victorian Studies 17 (2): 177-186.

Dickens, Charles. (1850) 2004. David Copperfield. New York and London: Penguin.

Eluss, Lorna. 1999. Appearing to Diminish: Female Development and the British Bildungsroman, 1750-1850. Lewisburgh: Bucknell U.P.

Freiman, Susan. 1993. Unbecoming Women: British Women Writers and the Novel of Development. New York: Columbia U.P.

GARDINER, Juliet. 1993. "Introduction". In Gardiner, Juliet (ed.) The New Woman: Women's Voices 1880-1918. London: Collins and Brown: 3-4.

Grand, Sarah. (1897) 2013. The Beth Book. London: Victorian Secrets.

Heilmann, Ann. 2000. New Woman Fiction: Women Writing First-Wave Feminism. London: Palgrave Macmillan.

Heilmann, Ann. 2004. New Woman Strategies: Sarah Grand, Olive Schreiner, Mona Caird. Manchester: Manchester U.P.

HIRSCH, Marianne. 1983. "Spiritual Bildung:The Beautiful Soul as Paradigm". In Abel Elizabeth, Marianne Hirsch and Elizabeth Langland (eds.): 23-48.

HIRSCH, Marianne. 1989. The Mother/Daughter Plot: Narrative, Psychoanalysis, Feminism. Bloomington: Indiana U.P.

Jung, Carl. (1951) 1990. The Archetypes and the Collective Unconscious. Trans. R.F.C. Hull. Princeton: Princeton U.P.

Kersley, Gillian. 1983. Darling Madame: Sarah Grand and Devoted Friend. London: Virago.
LeVINE, George. 2008. How to Read the Victorian Novel. Oxford: Blackwell.

Mangum, Teresa. 1998. Married, Middlebrow and Militant: Sarah Grand and the New Woman Novel. Ann Arbor: The University of Michigan Press.

MAYNARD, John R. 2006. "The Bildungsroman". In Brantlinger, Patrick and William B. Thesing (eds.) A Companion to the Victorian Novel. Oxford: Blackwell: 279-301.

PYKETT, Lyn. 1992. The 'Improper' Feminine: The Women's Sensation Novel and the New Woman Writing. London and New York: Routledge.

"Review of Sarah Grand (1897) The Beth Book". 1897. The Spectator 79: 691-692.

SALmon, Richard. 2019. "The Bildungsroman and Nineteenth-Century British Fiction". In Graham, Sarah (ed.) A History of the Bildungsroman. Cambridge: Cambridge U.P.: 57-83.

SAudo-Welby, Natalie. 2015. "Narratorial Authority in Sarah Grand's Beth Book (1897)" Études Anglaises 68 (1): 40-55.

Schaffer, Talia. 2013. "The Victorian Novel and the New Woman". In Rodensky, Lisa (ed.) The Oxford Handbook of the Victorian Novel. Oxford: Oxford U.P.: 730-744.

ShowAlter, Elaine. 1977. A Literature of Their Own. Princeton: Princeton U.P.

Shuttleworth, Sally. 2010. The Mind of the Child: Child Development in Literature, Science, and Medicine 1840-1900. Oxford: Oxford U.P.

SteAd, W.T. 1894. "The Novel of the Modern Woman". Review of Reviews 10: 67.

Sully, James. 1881. "Babies and Science". Cornhill 43: 542-545.

SutherLAND, John. 1989. The Stanford Companion to Victorian Fiction. Stanford: Stanford U.P.

TAYLOR, Jenny Bourne. 1998. "Between Atavism and Altruism: The Child on the Threshold in Victorian Psychology and Edwardian Children's Fiction". In LesnikOberstein, Karin (ed.) Children in Culture: 


\section{Ilona Dobosiewicz}

Approaches to Childhood. Basingstoke: Macmillan: 89-121.

TAYLOR, Jenny Bourne. 2013. "Introduction to The Beth Book". In Grand, Sarah. The Beth Book. London: Victorian Secrets: 5-16.

Woolf, Virginia. (1929) 1989. A Room of One's Own. New York and London: Harcourt Brace Jovanovich.
Youngkin, Molly. 2007. Feminist Realism at the Fin de Siècle: The Influence of the LateVictorian Woman's Press on the Development of the Novel. Columbus: Ohio U.P.

Received: 15/09/2020

Accepted: 14/05/2021 